\title{
The Proximate Composition of Edible Insects: Which Way Forward?
}

\author{
E.N. Amadi* \\ Department of Microbiology, Rivers State University of Science \& Technology, Nkpolu- \\ Oroworukwo, Port Harcourt, Rivers State, Nigeria \\ *Corresponding author
}

\begin{tabular}{|c|c|}
\hline & A B S T R A C T \\
\hline \multicolumn{2}{|l|}{ Keywords } \\
\hline $\begin{array}{l}\text { Proximate } \\
\text { composition } \\
\text { disparity, Edible } \\
\text { insects, Methods. }\end{array}$ & \multirow{3}{*}{$\begin{array}{l}\text { Nutritional composition of two edible insects, Rhynchophorus phoenicis } \\
\text { and Brachytrupes membranaceus from five different workers were } \\
\text { compared. Disparity as high as ca.54 percentage points was observed for B. } \\
\text { membranaceus and } 56 \% \text { for } R \text {. phoenicis. The disparity observed cannot be } \\
\text { attributed to whether or not wet or dry weight was applied. No two workers } \\
\text { used exactly the same method as there were subtle differences. The source } \\
\text { of these variations may actually be inherent in the methods. A standard } \\
\text { method is advocated for the proximate composition of edible insects. }\end{array}$} \\
\hline Article Info & \\
\hline $\begin{array}{l}\text { Accepted: } \\
\text { 28 August } 2017 \\
\text { Available Online: } \\
\text { 10 September } 2017\end{array}$ & \\
\hline
\end{tabular}

Introduction

Proximate composition, a common terminology in Food Science refers to the six (6) components of moisture, crude protein, ether extract, crude fibre, crude ash and nitrogen-free extract (carbohydrate). Moisture, crude protein, ether extract, crude fibre and ash are usually obtained through chemical reactions in experiments while carbohydrate is based on the determination of the other five using the difference method of Raghuramulu, et al., (1983). Proximate compositions should always add up to $100 \%$ as any deviation from $100 \%$ displays the resolution of the chemical test (Anon, 2017). It is not uncommon to see small variations in the way each test is performed by chemists or Food scientists. These variations accumulate, may overlap and affect the final result.
Furthermore, proximate composition is determined either on dry weight or wet weight basis; either way, it is expected that the results obtained should be comparable/similar within the limits of experimentation.

Proximate composition has been used extensively in the determination of the nutritional value of edible insects (Quin, 1964; Dreyer and Wehmeyer, 1982; Ohiokpehai et al., 1996; Bukkens, 1997; Wachukwu et al., 2002; Amadi et al., 2005; Ekpo and Onigbinde, 2005; Agbidye et al., 2009; Cerda et al., 2010; Adeyeye and Awokunmi 2010; Alamu et al., 2013; Amadi et al., 2014; Chakravorty et al., 2014; Amadi and Kiin-Kabari, 2016; Amadi, et.al., 2016a, 2016b). Amadi and Kiin-Kabari (2016) 
reviewed the nutritional composition and microbiology of some edible insects commonly eaten in Africa found disparity between the values obtained for the same insects by different workers and advocated the use of a comprehensive, standardised and universally acceptable method so that values obtained can be scientifically compared. Amadi, et al., (2016a) also called for a method that would lend itself to comparison and produce comparable and reliable data.

\section{Source of Data}

The data analysed here were taken from the works of Amadi, et.al. (2016b), Agbidye, et al., (2009), Adeyeye and Awokunmi (2010), Adeyeye and Awokunmi (2010), Ekpo and Onigbinde, 2005. All the workers claimed to use the standard method for proximate composition, i.e. AOAC (2012), although with subtle differences.

\section{Results and Discussion}

The data from the workers listed above are presented in tables 1 and 2. Table 1 shows the results obtained for Rhynchophorus phoenicis while table 2 represents that on Brachytrupes membranaceus. There is massive variation in the dry and wet weight values obtained for $R$. phoenicis by the same workers. Also variations abound between the values obtained by the different workers, the least being for carbohydrate. Comparing the values for B. membranaceus by Agbidye, et al., (2009) with those of Amadi, et al., (2016b) shows that the latter had lower values except for moisture; differing between 1 and 35 percentage points while moisture differed by 43 percentage points. When the data by Adeyeye and Awokunmi (2010) are compared with that of Amadi, et al., (2016b), the latter had higher values for moisture and fat while the former are higher in protein, carbohydrate and ash; varying between 5 and 50 percentage points. The data for the same insect by Adeyeye and Awokunmi (2010) are lower in moisture, protein and fat when compared with those of Agbidye, et al., (2009). Adeyeye and Awokunmi (2010) values are higher in carbohydrate and ash; the differences falling between 2 and 49 percentage points. It is worthwhile to note that the values for both workers were derived from dry weight! The data in tables 1 and 2 do not add up to $100 \%$. The proximate composition values from the work of Wachukwu, et al., (2002) are particularly striking as only three parameters add up to $114.40 \%$.

Table.1 Comparison of the proximate composition of Rhynchophorus phoenicis larva and adult weevil by various workers

\begin{tabular}{|c|c|c|c|c|c|c|c|c|c|}
\hline \multirow[t]{2}{*}{ Parameter } & \multicolumn{2}{|c|}{$\begin{array}{l}\text { Ekpo \& Onigbinde } \\
\text { (2005) }\end{array}$} & \multirow{2}{*}{$\begin{array}{l}\text { Wachukwu, } \\
\text { et.al. }(2002) \\
\text { Not Specified } \\
\text { (C) }\end{array}$} & \multicolumn{3}{|c|}{ Difference } & \multicolumn{2}{|c|}{$\begin{array}{l}\text { Amadi, et.al., (2014) Adult } \\
\text { beetle }\end{array}$} & \multirow{2}{*}{$\begin{array}{c}\begin{array}{c}\text { Differe } \\
\text { nce }\end{array} \\
\text { D-E }\end{array}$} \\
\hline & $\begin{array}{l}\text { DW } \\
\text { (A) }\end{array}$ & $\begin{array}{l}\text { WW } \\
\text { (B) }\end{array}$ & & A-B & A-C & B-C & $\begin{array}{l}\text { With chitin } \\
\text { (WW)D }\end{array}$ & $\begin{array}{l}\text { Without chitin } \\
\text { (WW)E }\end{array}$ & \\
\hline Moisture & - & 61.85 & ND & -61.85 & $\mathrm{NC}$ & $\mathrm{NC}$ & 56.82 & 52.88 & 3.94 \\
\hline Fat & 66.61 & 25.30 & 81.60 & 41.31 & -14.99 & -56.30 & 4.17 & 9.15 & -4.98 \\
\hline Protein & 22.06 & 8.38 & 30.30 & 13.68 & -8.24 & -21.92 & 32.71 & 26.85 & 5.86 \\
\hline Carbohydrate & 5.53 & 2.10 & 2.50 & 3.43 & 3.30 & -0.40 & 0.88 & 1.69 & -0.81 \\
\hline Ash & 5.79 & 2.20 & ND & 3.59 & $\mathrm{NC}$ & $\mathrm{NC}$ & 0.98 & 0.58 & 0.40 \\
\hline Fibre & ND & ND & ND & ND & ND & ND & ND & ND & ND \\
\hline TOTAL & 99.99 & 99.83 & 114.40 & & & & 104.15 & 97.55 & \\
\hline
\end{tabular}


Table. 2 Comparison of the proximate composition of Brachytrupes membranaceus obtained by various workers

\begin{tabular}{|l|l|l|l|l|l|l|}
\hline Parameter & $\begin{array}{l}\text { Agbidye, } \\
\text { e. al. } \\
(\mathbf{2 0 0 9})\end{array}$ & $\begin{array}{l}\text { Adedeye } \\
\text { and } \\
\text { Awokunmi } \\
\text { (2010) }\end{array}$ & $\begin{array}{l}\text { Amadi, } \\
\text { et. al. } \\
(\mathbf{2 0 1 6 a})\end{array}$ & \multicolumn{3}{|c|}{ Difference } \\
\cline { 2 - 7 } & $\begin{array}{l}\text { Dry } \\
\text { Weight } \\
\text { (A) }\end{array}$ & $\begin{array}{l}\text { Dry } \\
\text { Weight } \\
(\text { B) }\end{array}$ & $\begin{array}{l}\text { Wet } \\
\text { Weight } \\
(\text { C) }\end{array}$ & A-B & A-C & B-C \\
\hline Moisture & 11.60 & 0.90 & 54.49 & 10.70 & -42.89 & -53.59 \\
\hline Fat & 53.05 & 4.20 & 18.10 & 48.85 & 34.95 & -13.90 \\
\hline Protein & 35.06 & 29.10 & 20.22 & 5.96 & 14.84 & 8.88 \\
\hline Carbohydrate & 2.33 & 51.90 & 1.22 & -49.57 & 1.11 & 49.68 \\
\hline Ash & 3.25 & 5.70 & 0.97 & -2.45 & 2.28 & 4.73 \\
\hline Fibre & 6.30 & 8.20 & 5.0 & -1.90 & 1.30 & 3.20 \\
\hline TOTAL & 111.59 & 100 & 100 & & & \\
\hline
\end{tabular}

It would seem, therefore, that the disparity observed cannot be attributed to whether or not wet or dry weight was applied. No two workers used exactly the same method as there were subtle differences. The source of these variations may actually be inherent in the methods. A standard method is advocated for the proximate composition of edible insects.

\section{References}

Adeyeye, E.I., \& Awokunmi, E.E. 2010. Chemical composition of female and male giant African crickets, Brachytrupes membranaceus L. International Journal of Pharma and BioSciences 1(4): 126-136

Agbidye, F.S., Ofuya, T.I. \& Akindele, S.O. 2009. Marketability and nutritional qualities of some edible forest insects in Benue State, Nigeria. Pakistan Journal of Nutrition 8(7): 917-922.

Alamu, O.T., Amao, A.O., Nwokedi, C.I., Oke, O.A. \& Lawa, I.O. 2013. Diversity and nutritional status of edible insects in Nigeria: A Review. International Journal of Biodiversity and
Conservation 5(4): 215-222.

Amadi, E.N., and Kiin-Kabari D.B. 2016. Nutritional composition and microbiology of some Edible insects commonly eaten in Africa, hurdles and future prospects: A critical review. Journal of Food: Microbiology, Safety and Hygiene 1: 107. doi:10.4172/jfmsh.1000107

Amadi, E.N., Kiin-Kabari, D.B., John, G.D. and Solomon, E.C. 2016a Microbiological flora and proximate composition of the large African cricket, Brachytrupes membranaceus. EC Nutrition 5(3), 1150-1155.

Amadi, E.N., Kiin-Kabari, D.B., WilliamWest, D.P. and Pepple, G.E. 2016b Microbiological flora and proximate composition of the yam beetle, Heteroligus meles. International Journal of Current Microbiology and Applied Sciences 5(12), 370-375. doi:http://dx.doi.org/10.20546/ijcmas.20 16.512.040

Amadi, E.N., Kinn-Kabari, D.B, Kpormon, L.B. \& Robinson, V.K.K. 2014. Microbial flora and nutritional composition of adult Palm-wine beetle 
(Rhynchophorus

International Journal of Current Microbiology and Applied Sciences 3(11): 169-192.

Amadi, E.N., Ogbalu, O.K., Barimalaa, I.S. \& Pius, M. 2005. Microbiology and Nutritional composition of an edible (Bunaea alcinoe Stoll) of the Niger Delta. Journal of Food Safety 25: 193197.

Anon, 2017. https://en.m.wikipedia.org. Accessed on 1/3/2017

Bukkens, S. G.F., 1997. The nutritional value of edible insects. Ecology of Food and Nutrition 36:287-319.

Cerda, H., Martinez, R., Brinceno, N., Pizzoferrato, L., Manzi, P., Tommmaseoponzetta, M., Marin, O. \& Paoletti, M.G. (2010). Palm worm (Rhynchophorus palmarum) traditional food in the Amazonas, Venezuela. Nutritional composition, small-scale production and Tourist palatability. Ecology of Food and Nutrition 40(1): 13-32.

Dreyer, J.J., \& Wehmeyer, A.S. 1982. On the nutritive value of Mopanie worms. South African Journal of Science 78: 383-397
Ekpo, K.E., \& Onigbinde, A. O. 2005. Nutritional potentials of the larva of Rhynchophorus phoenicis (F). Pakistan Journal of Nutrition 4 (5): 287-290.

Jharna Chakravorty, Sampat Ghosh, Chuleui Jung, and V.B. Meyer-Rochow 2014. Nutritional composition of Chondacris rosea and Brachytrupes orientalis: Two Common insects used as food by tribes of Arunachal Pradesh, India. Journal of Asia-Pacific Entomology 17: 407-415

Ohiokpehai, O., Bulawayo, B.T., Mpotokwane, S., Sekwati, B. andBertinuson, A. (1996). Expanding the uses of phane a nutritionally rich local food in Botswana. In Phane, pp 84-103 Edited by B.A. Gashe \& S.F. Mpuchane. Proceedings of the first multidisciplinary Symposium on Phane.

Quin, P.J., 1964. Foods and Feeding Habits of the Pedi. Witwatersrand University Press, Johannesburg.

Wachukwu, C.K., Thomas, C.N. \& Kigigha, L.T. 2002. Microorganisms associated with Palmwine weevil larvae (Ryhnchophorus phoenicis). Journal of Dairying Food and Home Science 21(1): 44-47.

\section{How to cite this article:}

Amadi, E.N. 2017. The Proximate Composition of Edible Insects: Which Way Forward? Int.J.Curr.Microbiol.App.Sci. 6(9): 3033-3036. doi: https://doi.org/10.20546/ijcmas.2017.609.372 